\title{
The Role of Females in the Folk Media Industry of Nambale Sub County, Busia, Kenya
}

\author{
Jonai Wabwire \\ School of Information Science and Technology, Department of Communication and Media Studies, Kisii \\ University, P.O. Box 408, Kisii
}

\begin{abstract}
Folk media such as tales, songs, rituals, and drama, serves a descriptive, as well as prescriptive role, by unswervingly depicting societal and cultural norms. Chauvinistic portrayals sanction the marginality of Nambale Sub County women, particularly when these reflect prevailing gender responsibilities and expectations. However, contests over identity and representation are as ancient as unwritten history. An extensive exploration of various folk media productions from Nambale offers a wide range of role models for women; some of which depict female agency in exacting circumstances. Further, females as narrators, singers, actors, protagonists, and the primary audience accompanied with few men and children act as both custodians and creators of Nambale Sub County culture. The legitimacy of folk media such as tales and songs arises from their foundation in everyday sense experiences. Supplementary, the consistency of folk media types sanctions their legitimacy despite the selectivity in appropriation of cultural patterns. Further, while most Namable folk media forms portray women as less assertive, less ethical and often indecisive if not dependent on male folk; women nurture future generations and, through folktales, foster norms and values that maintain communities. Further, selfdetermined protagonists offer models of strategic, resourceful, daring, and visionary females. Whereas folktales reflect and sanction the subordination of women in society, most Nambale men maintain a protective stance toward mothers, while disparaging femininity.
\end{abstract}

Keywords: Kenya; folk media; gender and female agency; social norms; texts; cultural conduits; cultural identity; self-determined learning

DOI: $10.7176 / \mathrm{NMMC} / 82-04$

Publication date: August $31^{\text {st }} 2019$

\subsection{Introduction}

Political, social and economic structures provide a basis rather than determine individual choices in any given society; everyday activity, such as mothering or spousal choice decision making, can mirror previous actions (kinships rules) but also set a precedent. For the greater part, public's choices reflect learned behavior as everyday structures are embraced as tried and true. However, as some Nambale folk media artifacts like folktales and songs demonstrate, females have charted destinies over and above patriarchal demands and gender expectations. Similarly, females as narrators, singers or actors choose what to emphasize in folkloric texts and the audience selects what values to embrace from any one of the textual performances staged. It is these audiences that give the actors in folk media the audacity to exist. Without them the textuality in the texts becomes irrelevant. This is echoed by Barbers' (2005) assertions that if the audience has an active role in constituting the performance, cultural historians seeking to uncover histories of consciousness in African popular genres cannot afford to ignore it

The legitimacy of folk media such as tales arises from their foundation in everyday sense experiences. Supplementary, the consistency of folk media types sanctions their legitimacy despite the selectivity in appropriation of cultural patterns. Consequences for social breeches "legitimate action patterns and inform the operation of institutions that embody particular value patterns" (Smith, 2001, p. 26). Omissions of more egalitarian role types marginalize these positions, and ignore inevitable multi-perspectives in life; society's cultural sanction of male privilege in myths and reality subordinates women's status and interests. According to Namulunda $(2016$, p. 2) the process denies females a tradition of agency and solidarity. To this end, an interrogation of cultural conduits and norms allows communities to critique received social knowledge that undermines human fulfillment (Ramphele, 1990, p. 16): "What is at stake in social change is the most basic power of all: the power to define what and who is real, what and who is valuable, what and who matters" (Minnich, 2005, p. 262). As primary narrators, women are central to any community's curation and creation of cultural identities. Highlighting female agency legitimizes the place, interests, and capacities of an otherwise subordinated group.

Parentages transmit folkloric knowledge from numerous folk media productions through child rearing practices and instruction as well as through modeling of gender roles. This is well illustrated in the following song presenting mothers as the best cleaners of houses:

Mama niye weya

(My mother is the one who sweeps) 
Yamanya khweya nyumba

(She knows how to sweep the house)

Kukhu niye weya

(My grandmother is the one who sweeps)

Yamanya khweya inyumba

(She knows how to sweep the house)

Khukweyeresya, weya inyuma nende akari mwokhutekha

(In good sweeping, you sweep behind and around the cooking place)

In Nambale Sub County communities' role expectations reflect unequal power relations despite differences in receptivity and allegiance to received knowledge. A similar pattern appears in folk media performances which emphasize sexism and discount the presence of strong female role models in a society. Nevertheless, folktales and folk songs set up unrealistic portrayals that girls can reject, considering males are more exciting and female characters appear ridiculous. On the other hand, courageous, defiant, diligent, insightful, and visionary females demonstrate capacities for identifying problems and potential solutions, anticipating barriers, and considering consequences of various solutions (Mithaug, \& Martin, 2000).

As they sanction specific social values, communities dictate social roles and gender differentiations through stories and proverbs. In light of this, my deceased grandfather, Simon Magero, (d. June, 1993) along with younger conservative Luhya men and women in Nambale Sub County, would dismiss women's football as obusilu (foolishness). And that men watch women play football would elicit a dismissive grunt in a world of clearly defined gender roles, expectations, and aspirations. Sexist attitudes and practices within Nambale Sub County communities are not atypical. In his remarks after the opening of a Nairobi Conference for East African Women Parliamentarians on 6 March 2001, Kenyan President Daniel arap Moi attributed women's insignificant progress to their "little minds" (East African Standard; The Daily News, March 7, 2001). In 1989, at the height of the late Professor Wangari Maathai's opposition to former President Moi's "ego-driven 60-storey Kanu complex," he scolded her kind who had "dudus (insects) in their heads" (Warigi, 2011, p. 3). As both anecdotes illustrate, if male attributes (assertiveness, rationality, visionary, etc.) justify privilege, females exhibiting these qualities threaten existing gender divisions and, by extension, patriarchal structures. Females as well as males, who defy traditional gender roles, draw hostility or punitive shunning; men who participate in domestic chores in the presence of women are rebuked, as are women who assume roles traditionally restricted to men (Namulunda 2016). To maintain the façade of male supremacy, groups dismiss contradictory facts or imagery. In early October, 2000, about 100 Kenyan women demonstrated against the proposed Equality Bill, citing cultural imperialism during a landmark year of achievements. Purportedly, the Bill undermined cultural and customary gender roles.

Scholars such as Mysyk, (2007), points out women as mentors outlines their role in the process of lifelong learning. Mentors are a source of guidance in the audiences' significant transition, particularly, in adolescence and children (pp. 207-217). Stating that identity is socially and historically constructed, Mysyk identifies narrations, relationships, day-to- day choices and events as stimuluses on identity (pp. 211-214). Conformity means sharing the group's preferences and values. Most Nambale Sub County people derive their primary identity from membership in a family, kinship group, or ethnic group, a social bond between family members that spans generations. 


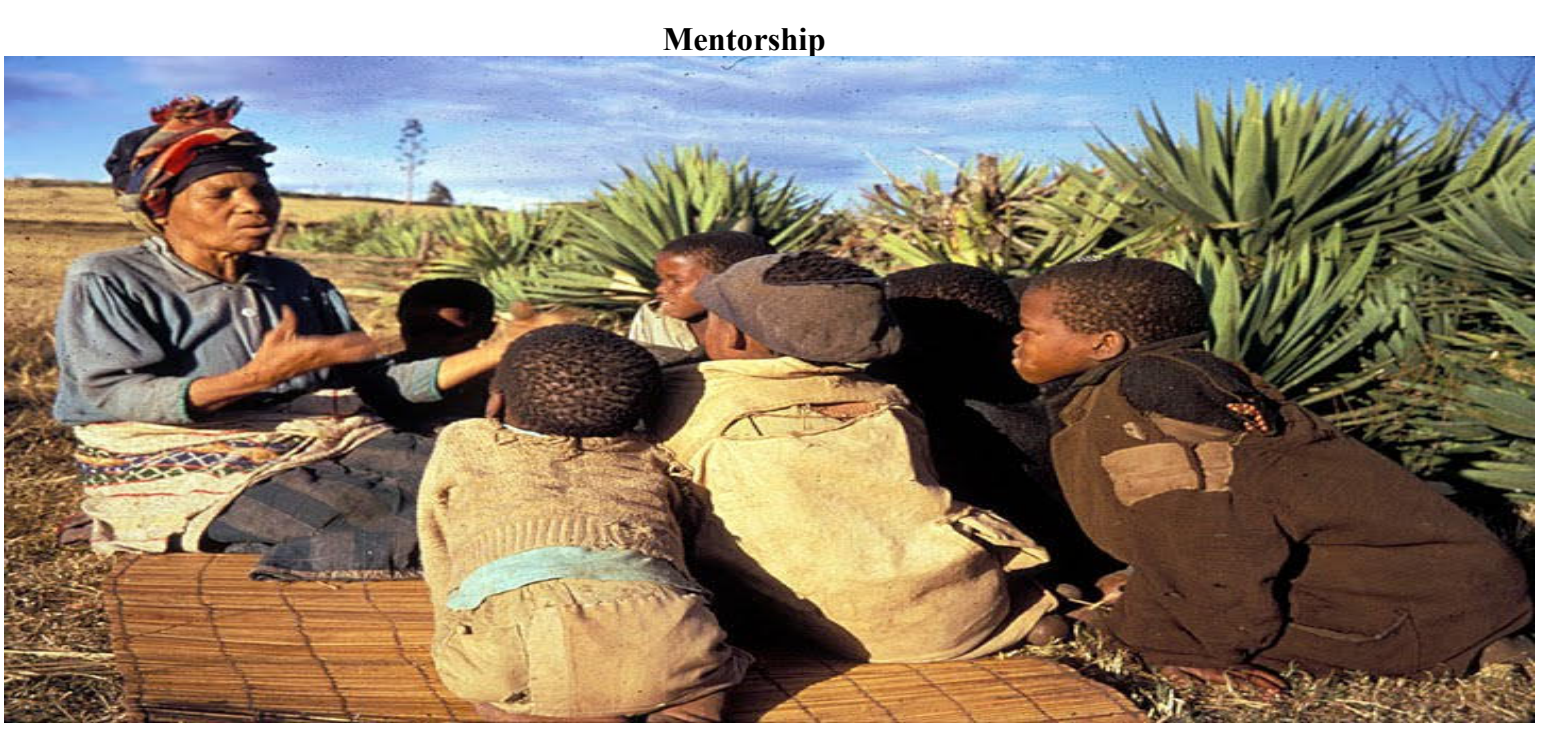

\section{A female narrator presenting to children of Emakina village of Nambale Sub-County, Busia, Kenya} Photograph taken by Jonai Wabwire, August 2018

Use of violence among men to outshine, wives, and children is commonplace in various types of folk media productions. The death penalty appears a primary corrective to social breaches. However, violence relativizes the value of human life, particularly women's lives. Mwangi (1983) justifies the lack of affectivity in such punitive extremes to a hostile environment that fosters uncompromising choices. Such rationale ignores the impact of modeled behavior upon impressionable youth. Deliberate omission of resistance to violence, excepting male confrontation of ogres, reflects distinct socialization patterns (Seppala, 1993, pp. 71-173). Abuses of power illustrate the asymmetry and dominance in relationships. Downplaying the threat, Ramphele (1990) sees the use of force over minorities as the lack of rather than an indicator of power (p. 11). In folktales, penalties follow deviations from an existing social order. The barren woman deserves no children. Sitati murders his brother-inlaw for his greed and insensitivity. The murderous Njabila and Ngoya die for taking the lives of spouses. Vindictive stepmothers lose their lives, or, at the least, their husbands' affection and loyalty. However, when bad things happen to good people, society has established retributive means of correction. Individual acts benefit or jeopardize the whole community and adults are cultural guardians.

Whereas Finnegan (1970) cautions against a functionalist reading of folktales by scholars, these are primary cultural conduit in communities with limited access to mass media networks (pp. 330-334). Tales or narrations are recited during impressionable adolescent years, when most young people are constructing identities and worldviews. The analysis of females in Nambale folk media industry exposes unexamined places of authority and privilege. Myth and reality depict "the world as a perilous place for women, a world where women are vulnerable, fearful, and despised" (Jordan \& Kalcik, 1985, p. 27). They are married off, or some predicament befalls them. Females who reject selected suitors or ignore male/social edicts are eventually subdued.

\subsection{The Implications of folk media textual productions in a given society}

Folk media productions reflect a group's cultural identity and serve as tools of education as much as entertainment in isolated communities. Folk media aids in the education of the young, promoting a group's feeling of solidarity, providing socially sanctioned ways for individuals to act superior to or to censure other individuals, serving as a vehicle for social protest, offering an enjoyable escape from reality, and converting full work into play. Appiah (1992) stresses the "self-validation" to a people accustomed to cultural definitions or omissions in literary texts to counter complexes from years of denigration and self-abasement. In Nambale Sub County folk media such as narrations, man is the ideal being. Events center on human life and occur within families. The human community epitomizes peace and order; resolutions to threats from ogres, individual breaches or natural disasters restore the social order. Heroes demonstrate their courage and significance of victory through hardships rather than a predestined calling in Luhya tales. Yet, folktales also reflect unexpressed contests of representation in depicting self-determined females and youth. Although African communities dismiss children's views, the destruction of a menacing ogre is averted by a child's initiative in, An Arranged Marriage.

Folk media underscore the realism and primacy of social identity as portrayed in Nambale folk narrations. Given the precarious existence, social cohesion may have been of greater significance than individual autonomy (Bisin 2011). Within social groups, folktales convey unconscious human desires and fears, striking a balance 
between the public faces of rationality and sentimentality (Jones, 1965, pp. 88-102). The overt prohibition of socially disruptive behavior in public may account for the depiction of ogres and animals as embodying antisocial fantasies (Miruka, 1994, pp. 170-174). Thompson (1996, pp. 392-398) links the presence of ogres in narrations to imagined fears of death and a natural desire to overcome it or its personification but cautions against looking for psychoanalytic interpretations of myths and folktales. Miruka views folktales as occasionally portraying ogres positively in order to emphasize the vice of man. The ogre in Mulongo and Wacheche the Ogre, manifests socially desirable traits in its interaction with humans. In this light, women become the shadow on which society projects the other when the masculine is the norm.

Folk media as educative and instructional tool provide a network of meanings for cultural norms and practices, what Bascom (1996) terms image and its images of other groups; although he acknowledges differences between folk media productions and culture (p. 268). In his analysis of the role of psychological and institutional defense mechanism in times of change, Akong'a (1997, pp. 3-19) illustrates how social norms provide stability and consistency by prescribing social roles and behaviors. As cultural and moral ideals, folk media characters legitimize modes of social existence. Namunguba and His Brother-in-Law Sitati portrays an occupation, kinship alliances, relational tensions, greed, revenge, etc. On the other hand, the image of folktales as frivolous entertainment, undeserving of scholarly attention, undermines their legitimacy (Finnegan, 1970, pp. 25-47), compared to "masculine" oriented historical traditions and memories purportedly based on fact and targeting a relatively adult audience (Pender-Cudlip, 1972, pp. 3-24). Yet, folktales highlight women's activities and their role in cultural transmission, particularly the immediacy of everyday tensions, resolutions, and world views; what Jordan and Kalcik (1985, p. xiv) term the "complexities of human culture as seen from multiple perspectives." However, the subordination of the genre, devalues women as its primary representatives.

Ramphele (1990) defines power as the capacity to use resources to secure outcomes as well as both defining and constructing symbols. Societal language captures and reinforces social meaning, women as composers and storytellers help to define reality as well as transform structural inequalities. Women's complicity in sanctioning male privilege raises questions of responsibility. In Enchanted Maidens: Gender Relations in Spanish Folktales of Courtship and Marriage, Nahuat and Mayan women, comparable to women elsewhere, promote their own subordination by socializing children according to the values of the male-dominant public culture (Taggart, 1990, pp. 219-224). Among the Marakwet and kipsigis of Kenya, similar to neighboring communities, the privilege of constructing social meaning is primarily based on gender and age although Moore acknowledges that "power does not operate in a uniform and monolithic way" (1986, p. 194). The position transcends an acceptance of historical gender ordering at the center of academic and ideological discourse. While appealing to human emotions, folk media of various types foster assessments of prevailing philosophies (De Vos \& Altmann, 1999, p. 23). In this light, assertive females typify alternative albeit sidelined identities.

Implication of narrations to children in the process of forming an identity cannot be understated. Since evil consistently befalls violators of social norms as Namulunda (2016) puts, one has to assume that tales discourage such traits in humans, albeit implicitly. Stone (1985, p. 125) wonders whether tales are "damaging because of their violence or irrationality, or whether they instead furnished powerful fantasies good for developing psyches." The consistency in depicting women as subordinate in character, sanctions prevailing sexist beliefs and practices. Stone admits that most tales depict "young girls who are passive and helpless ... (powerful women) are older (and) often wicked stepmothers" (p. 127). Smith (2001, p. 59) acknowledges the impact of myth, but recognizes differences in how people "create and use meaning." The depiction of Nambale women captures incidents of agency as much as structural influences on choice. Although beholden to men in large part, female protagonists in, Namulunda the Neglected Wife, an Old Lady, a Young Woman and the Ogres, as well as The Ogres and the Infant, orchestrate resolutions to predicaments absent male audience or assistance.

The Nambale Sub County communities use various folk media types for entertainment and education (edutainment), but primarily as a bonding ritual. Setting folk media in a fantastic, non-human world lifted the minds of audiences to a world without limitations and blissful wish fulfillment (Rohrich, 1991, pp. 92-111). Audiences tolerate atypical behavior, such as talking animals, marriage between ogres and humans, sadistic acts, and unnatural escapes without rationalistic deliberations. As such staging any folk media to awrong audience makes it irrelevant. In Khangaliba, the Boy and the Ogre, the bride-to-be is stuffed in a tree hole. Also, in The Girl with the Unique Scarifications and The Ogres and the Infant, humans conjure hailstorms and lightning, respectively. The Barren Woman acquires children from bark skins. In myths, nothing is impossible. Such aberrations in folk narrations make the omission of women in leadership roles conspicuous and prescriptive. The portrayal of courage, adventure, control over families and resources, could just as frequently be depicted by either gender. There could also be depictions of women beating up husbands mercilessly or ogres taking over human communities and carrying out their daily activities just like humans do.

\subsection{Themes in Nambale Sub County Folk media productions}

Plots in various folk media productions vary in location of performance, historic period in which they are 
composed or produced and the performance styles in which they have to be staged to the audiences. Names of songs, tales, plays etc. consistently reflect cultural roles and expectations. Repetitive themes in Bakhayo tales of Nambale include, stubborn women, drunkard men, jealous stepmothers, human and non-human interactions, neglected wives, the plight of orphaned stepchildren, contests of wit and physical stamina, ecological disasters, a threatening environment, human resilience, domesticated animals, domestic chores, community life, scarification of young girls, etc. The heroes are ordinary farmers, shepherds, stepmothers, husbands, and orphans, all of who represent common social roles. In narrations, the audiences meets Nyaranga, the ironsmith; Namunguba and Sitati, the hunters; Namulunda, the neglected wife; Lukela and Lutomia, the malicious stepmothers; the barren women, Mukoya and Namuyemba; Manyonge, the hunter; Khayonga, with the unique scarifications; Kulundu, the shepherd; etc. Animals and ogres also have names: Khole, the unique bull; Menumenu, Muangakiekulu, and Wacheche, the ogres. Regardless of plot, males come off in better light than females whom tales frequently portray as negative, gullible, and reckless beings. Within marital arrangements, defiant females are subdued, infertility is attributed to a woman's moral culpability, bride wealth settles parental concerns for daughters, and in polygamous unions stepmothers exploit vulnerable stepchildren.

\subsubsection{The over glorification of Males in Nambale folk media performances}

Folk media portray males as visionary, responsible, courageous, and with inordinate power. Women come off as an alter ego. Even male children exhibit a perception that is lacking in adult females. They are regarded more powerful than women. Most folk media portray males in authority and as individuals who have power over death. In myth and reality, male privilege is founded on control "over the means of production, land, and cattle" (Nasimiyu, 1997, p. 284). Male interests prevail including, the choice of spouses, bride wealth, and living arrangements. In An Arranged Marriage and Khachelechenje, Khayanga, and Makokha's family, respectively, promise daughters to marriage partners they neither know nor particularly appear to desire. That husbands pay bride-wealth may further reinforces the marginality of women. To the present, most luhya men within and outside Nambale Sub County define masculinity as outgrowing female-related traits and characteristics including childishness and lack of autonomy. As household heads, fathers protect families by their presence and ensure security in their absence. None of the Luhya narrations depict ogres attacking homes unprovoked; incidents which are frequently instigated by a female's breech. In both Nyaranga the Ironsmith and the Ogre as well as Nalubanga and her Brother Tukhila, the brothers warn female siblings against ogres and Tukhila even resuscitates his sister by rejoining her skeleton bones after the ogres make a meal of her. Male kin are portrayed as powerful, protective, ingenious, and diligent. The rescue effort is replete with male imagery.

Folk media performances frequently portray women at work, rather than at leisure oriented beer feasts and dance gatherings. In communities, women's domestic chores relieve governments of funding for social programs, such as child/elderly care, crucial to community welfare. However, men occupy the climax of authority structures. Communities relegate girls to domestic and child rearing roles, under the supervision of males and adult females. Females are confined to the domestic sphere and engaged in subsistence occupations: farming, collecting firewood, rummaging for vegetables, fetching water, and raising children. In Kasaawa and the Garden of Pumpkins, males congregate at beer-fests, while wives are depicted in domestic spheres, engaged in farming, threshing of millet and childcare. Only in The Daughters of Chiefs Sudi and Namutala, do two girls attend a courtship ceremony. Although women hold extensive responsibilities in the domestic sphere, men retain ultimate decision-making power on what transpires in and outside homes. In Kasaawa and his Garden of Pumpkins, the husband forbids his wife Mukoya to harvest from one of the plots before undertaking an extended trip. Children die from eating the forbidden produce after exhausting the allotted portion. Upon his return, the husband resurrects his children by stroking them with a medicinal herb, lufufu: capricious men, perhaps, but powerful enough to resuscitate dead children. Children die and are resurrected; voiceless in life and nameless in death. The luhya proverb Nandakererwa yakona khumwanda kwa injoli (fools rush in where angels fear to tread!) cautions youngsters against disregarding the advice of elders. In spite of conventional platitudes regarding the value of children, folktales portray children as unreliable at best. Perhaps reflecting the conventional cliché of children being seen rather than heard, few folktales center on children alone. Injunctions of children "being seen, nor heard," capture the cultural subordination of children's visibility and interests.

In most homes in Nambale children are a primary source of labor. Brides earn dowry for exploitive parents. Rural families indenture their children to wealthier relatives and patrons in urban centers. The Kenyan modern media ran a series on Nairobi "Bureaus that turn girls (ayahs) into chattels," with some girls as young as ten (Omukhango, 1998). To date, as indentured workers, most live under a shroud of fear, enduring physical, emotional, and sexual abuse at the hands of employers, particularly, fellow women (they are hired as maids). Stories of jealously malicious stepmothers epitomize abusive relations within polygamous families. The recurrence of scheming stepmothers in Luhya folktales probably demonstrates women's resistance to polygamous unions. Aware of the partiality in such unions, co-wives resist traditional mores experienced as oppressive, albeit underhandedly. There is an obvious contrast between the narrations of orphaned male and female children, despite similarities in plight. In The Girl with Unique Scarifications, as well as Nalubanga and 
her Brother Tukhila, female victims are rescued from their predicament by third parties. However, in Simbi and Syuma, the male orphan subverts the plot of a scheming stepmother and emerges with notable success. In myth and life, children can play a crucial role. Female siblings in Kangaliba, the Boy and the Ogre, initiate a bride into her marital community and expose an ogre that dupes both bride and groom.

\subsubsection{Females and their commodification in folk media performances}

Folktales consistently portray women in domestic roles, gullible to the lures of ogres and strangers, and dependent upon men folk. Making reckless choices, girls endanger their lives and the community's welfare. Girls are married off to spouses they neither know nor care for. Women exploit stepchildren in the absence of adult males. Also, despite elements of distributive justice in folktales, women, more frequently than men, lose their lives. Transgression, or rather, independence, in women, regarding spouses, is at the expense of community protection and goodwill. That assertive women suffer for overstepping their boundaries, reflects reality; "many females find fairy tales an echo of their own struggle to become human beings" (Stone, 1985, p. 144). The females in The Girl who Rejected Suitors and A Girl Called Sisiwe are both eventually tricked into marriage, deflating any notion of female autonomy outside a prescribed marital ideal. The caveat against undue pride and self-assertiveness in females reflects the futility of such ambitions but also the primacy of community over individual interests; except in males. Yet, the girls' dissenting voices and the fact that stories are named after them reflect an agency. Besides compromising women's ability to accumulate wealth, cultural definitions and practices limit individual women's overall independence. The Girl who Rejected Suitors, loses protection and goodwill for denying the community bride-wealth. The abducted daughter's father concedes to the marriage and accepts the dowry. Opponents of the system point to excesses, the commodification of women and the financial strain on newlyweds in addition to a "legitimized male appropriation of female and child labor" (Nasimiyu, 1997, p. 289). Some view it as a symbol of the wife's material and emotional backing. Namulunda the Neglected Wife benefits from her natal family's protection against a callous husband. Wagner (1949) acknowledges the price girls pay in marriage: it "means for a girl that she has to leave her parental home and join a group of persons who will make numerous demands upon her and who often will show a very critical attitude towards her accomplishments and her conduct as a wife" (p. 380).

Females are believed to be irresolute and divisive, in contrast to men, who are focused, responsible, and visionary, in Minnich's (2005) terms, the man's alter ego (p. 195). Societies like the Marakwet, tugens, pokots etc of Kenya use adjectives like "individualism," "thoughtlessness," and "uncontrollability" for females while "maleness may become associated with a series of things like, 'big', 'sky', (and) 'right"” (Moore, 1986, p. 168). The subordination of women reflects dominant representations of gender in language as well as day-to-day village beliefs and practices that reproduce power relations (pp. 155-188). Apart from Weswa in The Ogre that Lost its Tail and the Two Dogs Kutubi and Namulikho and the man duped by The Squirrel and Hyena, gullible females, rather than males, fall prey to ogres. In An Arranged Marriage a group of damsels in distress are eventually rescued by one of the fathers, Tunde, the son of Walianda. He is out and about in places females and children frequent to collect firewood. Alternatively, communities live in such harmony that socially destructive behavior, when it occurs, is unexpected. However, in Simbi and Syuma the orphaned child overhears the plot against his life and tricks the stepmother into killing Syuma her own son. Folktales portray boys as more perceptive of strained relations. Manifestly, cultural distinctions arise much earlier or else, are innate in boys.

Nambale Sub County narratives depict women as voiceless individuals, less intelligent than men, as domestic aides, totally dependent on men and overcome by jealousy and malice. Moore (1986, p. 164) links gender representation and perception to everyday relationships between men and women. The division of labor, organization of marriage, household structures and gender specific judicial status within communities, reflect and reinforce gender conceptualizations and hierarchical arrangements. In communities, politicians and their precursor village chiefs, command in ordinate power and wealth from gratuitous pledges. Across the country, men dominate the public sphere in representation and decision-making power. In the search for identity and place, females face tremendous hurdles including conformity to traditional gender roles coupled by limited education access (Barasa, 2007). Clinton (2010) highlights the ongoing plight of women: Women are still the majority of the world's poor, uneducated, unhealthy, unfed. They are the majority of the world's farmers, but are often forbidden from owning land they cultivate or accessing credit. Women care for the world's sick, but women and girls are less likely to get treatment. They rarely cause armed conflicts but always suffer consequences and are often excluded from peace talks. And violence against women remains a global pandemic.

While Ramphele (1990) roots unequal relations in gender, class, race, geographic region, age, etc., not all women are similarly disadvantaged (pp. 7-17) as postmodern feminism illustrates: "while some women share some common interests and face some common enemies, such commonalities are by no means universal; they are entwined with differences, with conflicts." (Fraser \& Nicholson, 2011, p. 235) Nambale folk media such as tales capture this disparity in depictions of women's agency, however ambivalently. Representation of independent women who use power destructively undermines their moral authority. Although marginalized by patriarchal structures, older or economically privileged women readily exploit female dependents, particularly in 
domestic spheres. The Barren Woman is happy to acquire children who help out with chores but exploits them; especially, the hunchback who runs errands in the home and is also in charge of drying Mukoya's medicinal concoctions. Women find their identity in childbearing and the association to the male as brother, father, and husband. And matchmakers have their fee, especially from well-endowed grooms and families.

Scholars such as Okpe (1999, p. 127) attributes the marginalization of some women to old age or the possession of "questionable traits of character or unspeakable acts that automatically disqualify them from ordinary interactions." Most Nambale Sub County marriages are formalized at the birth of the first or second child. Since social maturity is tied closely to lineage, reproduction makes a man and barren women lack purpose and worth (Moore, 1986, p. 58). Barren women are hermits in folktales and real life, and childlessness is viewed as a penalty for personal or moral inadequacy. Seemingly, cultural beliefs tramp science; African communities attribute infertility to women for whom it signifies, "a punishment from God or wrath of the ancestral spirits for sins committed, usually by the woman" (CREAW, 2011, p. 10). Indeed, The Barren Woman exonerates the husband by absentia. She suffers the loss of helpers for being insensitive to a handicapped child and for her exploitation of his siblings. By implication, the protagonist is guilty of moral failure, absolving a system that privileges a few. In contrast, “... Impotence of the husband, on the other hand, may disrupt a marriage for reasons of sex but hardly for reasons of procreation, as with the husband's tacit agreement one of his brothers step into his place" (Wagner, 1949, p. 43). Yet again, sexist imagery and language limits the aspirations of females and ennobles masculinity.

Regardless of overwhelming portrayals of female incapacities, the mother in, The Ogres and the Infant, single handedly saves her family from starvation. She scouts an ogres' homestead and farm, orchestrates an illicit harvest in the night losing her infant in the process. She successfully strategizes the rescue of her child and destroys all the ogres. In the end, she assumes ownership of a farm of bounteous pumpkins to the family's benefit. In communities, women's political visibility and gains in access to resources also compel negotiations of mainstream knowledge and the prevailing patriarchal order. Supplementary, the breakdown in kinship ties and tradition coupled with encroaching urbanization and greater access to education across gender trigger cultural redefinitions. Challenges to dominant discourses come at a great expense as both reality and myth demonstrate.

\subsection{Empowering models}

Folklores sanction existing social values, but also subvert existing social arrangements by providing "socially approved outlets for the repressions which these same institutions impose" (Bascom, 1996, p. 298). Tales portray contrasting forces of good against evil, cleverness against the stupidity, heroes against villains, favored spouses against neglected ones, all of which reflect the ambivalence in the lives of most listeners. In terms of gender, folktales and other folk media in Nambale depict women as narrators, nurturers, laborers, and some with inordinate power over nature. Even though Nambale folk media reflect a gender hierarchy, female agency disputes this essentialist view of women's ineptitude, as the stories of Namulunda the Neglected Wife, an Old Lady, a Young Woman and the Ogres, as well as The Ogres and the Infant illustrate; female heroines orchestrate the resolution of predicaments. In The Ogres and the Infant, a mother-in classic Western-style adventurerescues her daughter and destroys a whole herd of ogres, in the process gaining access to a bounteous plantation of pumpkins during a famine. At the end of the tale, her husband and family assume ownership, although conspicuously absent during the woman's plight and eventual feat. Similarly, in An Old Woman, a Young Girl and the Ogres, an old lady organizes a narrow escape, camouflaged in manure to repulse the ogres enroute, while the young girl parts waters for them to cross over to safety and human territory, reminiscent of the renowned Exodus experience in the Jewish and Christian scriptures. The subversive quality of these tales and those portraying males as capricious or non-humans with desirable characteristics cannot be overlooked.

Namulunda (2016, p. 10) links "tales of self-assertion" to "recognition of identity, and equality in the political playing field." Mainstream ideologies tend to promote selective social knowledge. The absence of women's voices, resilience, and self-assertion illustrates the partiality in those cultural histories and within social mores. In 1913, the Giriama Mekatili Wa Menza led a rebellion against the Colonial administration's policies and in 1922, Mary Nyanjiru faced the colonists gun when men refused to fight (Ikonya, 2008). The 2004 Nobel Peace Prize Laurent Dr. Wangari Maathai (2006) consistently fenced off political silencing in her memoir, Unbowed. The notoriety of Mekatili, Mary, Wangari and folktale depictions of autonomous women illustrate either their rarity or a lack of visibility in Kenyan communities. What are the "silences," in Nambale folk media productions? Scheming stepmothers reflect conventional views regarding the partiality of stepmothers in polygamous unions, despite the existence of impartial stepmothers. A similar correction applies to models of diligent youth, protective fathers, or for that matter, harmonious communities. Breaches of social roles pose a threat to gendered ideologies in African communities. Contrastingly, independent women develop the space and authority to reassess allegiances and reverence to prevailing structures. They depict females in control of destinies and as catalysts of social change. In The Story of Nasio, a father mistakenly marries off the daughter to an ogre. Nasio plans her escape back to her natal homestead after the birth of the first child which gives her time 
to consider options and risks. Even then, an ogre clings to her and has to be beaten off with the help of Nasio's brother Muabini. There is a wide range of role models, some more obvious than others. On the other hand, that women recount disempowering folktales raises questions of agency as much as perception and responsibility.

From keen observation of Kenyan political sphere, women's economic and political Women account for $53 \%$ of Kenya's electoral vote but yet society marginalizes their tasks, traits, and characteristics in myth and reality. Okpewho $(1999$, p. x) acknowledges that "myth reflects the structure of relations between people but ultimately the implications for contemporary society of prejudices inscribed in those relations." He attributes the misogyny in folktales to women's acceptance of the "religious or cultural tradition which puts women on a lower rung of the social ladder, and sees little need to alter the facts of the tale and upset the order of things" (1983, p. 91). Although women and men have different perceptions of reality, both are enmeshed in existing structures of meaning and practice, in this case, a gender hierarchy: "Women are not 'free' from the images society provides them; they are socialized, just as forcibly as men, into accepting social norms and values. When women construct representations of themselves, they do so using the material which the socially dominant representations of women provide" (Moore, 1986, p. 184). As tokens in male-dominated fields like sports, "women respond to performance pressures, heightened visibility, and gender adversity by embracing stereotypical roles and behaving accordingly (Sartore \& Cunningham, 2007, p. 251). Seemingly, sameness is inextricably linked to differences. One understands man by what he is not and vice versa.

\subsection{Conclusion}

Folk media offer an alternative view to historical narratives dominated by male narrators and ideals. Narrators and performers, most of whom are women and youth, uphold traditional beliefs and shape the construction of identities. Of great concern is the sexism in folk media productions and performances, which is prevalent, even though narrators are primarily women. Further, while most Namable folk media forms portray women as less assertive, less ethical and often indecisive if not dependent on male folk; women nurture future generations and, through folktales, foster norms and values that maintain communities. Further, self-determined protagonists offer models of strategic, resourceful, daring, and visionary females. Whereas folktales reflect and sanction the subordination of women in society, most Nambale men maintain a protective stance toward mothers, while deriding femininity. The worst insult within Nambale communities is ("Kumao," literally, "Your mother!") as with other Kenyan ethnic groups, in which the denigration of an opponent's mother is equally used. It is a sure way of picking a fight. Nonetheless, a primary threat to masculinity is highlighting a man's "femininity," involving associations to the domestic and a sense of vulnerability. Are men protective of women for their vulnerability or because of their valued status? Paradoxically, men and women, readily recount women's ineptitude, while chiding those that transgress gender-based roles and expectations.

Sexist imagery trivializes women's lives and contributions; however, the economic and political dominance of men, as well as overrepresentation in education and media fails to explain the subordinate status of women worldwide given stories of female agency. On the other hand, in Nambale folk media, women who accomplish feats or use power destructively, do so in the absence of adult males. By acknowledging female agency in predominantly female settings, folktales avoid confronting male supremacy and, by extension, a gender hierarchy, in domestic and public spheres. It appears as though men thwart women's ambition or that females fall short of a male norm of excellence. Ramphele finds the portrayal of women as victims both patronizing and paralyzing. Story telling provides a context for negotiating meaning including gender depictions.

\section{References}

Akong'a, J. (1997). Psychological and institutional defence mechanisms in times of change. In T. Weisner, C. Bradley, \& P. L. Kilbride (Eds.), African families and the crisis of social change (pp. 3-19). Westport, CT: Bergin \& Garvey.

Appiah, K. A. (1992). In my father's house: Africa in the philosophy of culture. New York, NY: Oxford University Press.

Barber, K (1997) "Time, space and writing in three colonial Yorub'a novels", The Yearbook of

Barber, K (1997) “Time, space and writing in three colonial Yorub'a novels", The Yearbook of

Barber, K. (2005) Text and Performance in Africa. Journal of Oral Tradition, 20/2 (2005): 264-277.

Barasa, S. (2007). G21 Africa: Kenyan women in politics. Retrieved December 3, 2016, from http://www.g21.net/ africa101.html

Bascom, W. R. (Ed.). (1996). Folklore and anthropology. The study of Folklores. Englewood Cliffs, NJ: Prentice-Hall.

Bisin, A., Patacchini, E., Verdier, T., \& Zenou, Y. (2011). Formation and persistence of oppositional identities. European Economic Review, 55, 1046-1071.

Chesaina, C. (1994). Images of women in African oral literature. In A. Bukenya, W. K. Kabira, \& O. Okoth (Eds.), Understanding oral literature (pp. 85-92). Nairobi: Nairobi University Press. 
Clinton, H. (2010). World is better off saluting the strength of a woman. Nation on the Web. Retrieved March 28 , 2015, from www.nation.co.ke/Opninion/World

De Vos, G., \& Altmann, A. E. (1999). New folktales for old: Folktales as literary fictions for young adults Englewood, CO: Libraries Unlimited.

Dundes, A. (1965). The study of Folklores. Englewood Cliffs, NJ: Prentice-Hall.

Felski, R. (2011). Doing time: Feminist theory and postmodernist culture. In M. Eagleton (Ed.), Feminist literary theory: A reader (3rd ed., pp. 37-41). Malden, MA:

Wiley-Blackwell. Finnegan, R. (1970). Oral literature in Africa. Oxford: Clarendon Press.

Fraser, N., \& Nicholson, L. J. (Eds.). (2011). Social criticism without philosophy: An encounter between feminism and postmodernism. In M. Eagleton (Ed.), Feminist literary theory: A reader (pp. 234-235). Malden, MA: Wiley-Blackwell.

Giray, E. (1996). Nsiirin! Nsiirin!: Jula folktales from West Africa. East Lasing, MI: Michigan State University Press.

Gorog-Karady, V. (1995). Tales and ideology: The revolt of sons in Bambara-Malinke folktales. In G. Furniss \& L. Gunner (Eds.), Power, marginality and African oral literature (pp. 83-91). New York, NY: Cambridge University Press.

Ikonya, P. (2008). Kenya is burning: Voices are missing in the making of the nation. Retrieved May 15, 2012, from http://www.thewip.net/contributors/2008/03/kenya_is_burning_womens_voices.html

Jones, E. (1965). Psychoanalysis and folklore. In A. Dundes (Ed.), The study of folklores (pp. 88-102). Englewood Cliffs,

NJ: Prentice-Hall. Jordan, R. A., \& Kalcik, S. J. (Eds.). (1985). Women's folklore: Women's culture. Philadelphia, PA: University of Pennsylvania Press.

Maathai, W. M. (2006). Unbowed: A memoir. New York, NY: Anchor Books.

Minnich, E. K. (2005). Transforming education (2nd ed.). Philadelphia, PA: Temple University Press.

Miruka, O. (1994). Encounter with oral literature. Nairobi: East African Educational.

Moore, H. L. (1986). Space, text and gender: An anthropological study of the Marakwet of Kenya. Cambridge: Cambridge University Press.

Mwangi, R. (1983). Kikuyu folktales: Their nature and value. Nairobi: Kenya Literature Bureau.

Mysyk, N. F. (2007). Women becoming mentors: Reflection and mentor identity formation as a process of lifelong learning. The International Journal of Diversity in Organisations, Communities and Nations, 8, 207-217.

Namulunda, F. (2016) International \& Comparative Education female role models in bukusu folktales: education at the mother's hearth cogent education (2016), 3.

Nasimiyu, R. (1997). Changing women's rights over property in Western Kenya. In T. Weisner, C. Bradley, \& P. L. Kilbride (Eds.), African families and the crisis of social change (pp. 283-298). Westport, CT: Bergin \& Garvey.

Nasong'o, S. W., \& Ayot, T.O. (2007). Women in Kenya's politics of transition and democritisation. In G. Murunga \& S. W. Nasong'o (Eds.), Kenya: The struggle for democracy (pp. 164-196). New York, NY: Codesria Books/Zed Books.

Okpewho, I. (1983). Myth in Africa: A study of its aesthetics and cultural relevance. Cambridge: Cambridge University Press.

Okpewho, I. (1999). Once upon a kingdom: Myth, hegemony, and identity. Bloomington, IL: Indiana University Press. Omukhango, R. (1998, November 10). Bureaus that turn girls

into chattels. Daily Nation on the Web.

Pender-Cudlip, P. (1972). Oral traditions and anthropological analysis: Some contemporary myths. Azania: Archaeological Research in Africa, 7, 3-24.

Ramphele, M. (1990). Do women help perpetuate sexism? A bird's eye view from South Africa. Africa Today, $37,7-17$.

Rohrich, L. (1991). Folk Media and reality. (P. Tokofsky, Trans). Bloomington, IL: Indiana University Press.

Sartore, M., \& Cunningham, G. B. (2007). Explaining the under-representation of women in leadership positions of sports organizations: A symbolic interactionist

perspective. Quest-Illinois-national Association for Physical Education in Higher Education, 59, 244-265.

Seppala, P. (1993). The changing generations: The devolution of land among the Babukusu in Western Kenya. Helsinki: Finnish Anthropological Society.

Smith, P. (2001). Cultural theory: An introduction. Malden, MA: Blackwell.

Stone, K. F. (1985). The misuses of enchantment: Controversies on the significance of fairy tales. In R. A. Jordan \& S. J. Kalcik (Eds.), Women's folklore: Women's culture (pp. 125-145). Philadelphia, PA: University of Pennsylvania Press.

Swartz, D. (1997). Culture and power: The sociology of Pierre Bourdieu. Chicago, IL: University of Chicago 
Press.

Taggart, J. M. (1990). Enchanted maidens: Gender relations in Spanish folktales of courtship and marriage. Princeton, NJ: Princeton University Press. The Center for Rights Education and Awareness. (2011). Status of women \& girls in Kenya: Urgent need to uphold human rights. Nairobi: Ministry of Health. Retrieved May 18, 2012, from http://www.creawkenya.org/creaw-publications/thestatus- of-women-and-girls-inkenya.html

Thompson, S. (1996). Myths and folktales. In A. Robert Segal (Ed.), Anthropology, folklore, and myth (pp. 392488). New York, NY: Garland.

Wagner, G. (1949). The bantu of North Kavirondo (Vol. 1). London: Oxford University Press.

Wandibba, S. (1997). Changing roles in the Bukusu family. In T. Weisner, C. Bradley, \& P. L. Kilbride (Eds.), African families and the crisis of social change (pp. 332-340).

Westport, CT: Bergin \& Garvey. Warigi, G. (2011, September 28). Maathai shunned elitist life to stand for ordinary people. Nation Newspapers, pp. 1-2.

Wehmeyer, M. L., Palmer, S. B., Agran, M., Mithaug, D. E., \& Martin, J. E. (2000). Promoting causal agency: The self-determine learning model of instruction. Exceptional Children, 66, 439-453.

Wipper, A. (1978). Rural rebels: A study of two protest movements in Kenya. Nairobi: Oxford University Press. 